\title{
Genome sequence reveals that Pseudomonas fluorescens F113 possesses a large and diverse array of systems for rhizosphere function and host interaction
}

Miguel Redondo-Nieto ${ }^{1 \dagger}$, Matthieu Barret ${ }^{2,3+}$, John Morrissey ${ }^{3}$, Kieran Germaine ${ }^{4}$, Francisco Martínez-Granero ${ }^{1}$, Emma Barahona', Ana Navazo ${ }^{1}$, María Sánchez-Contreras', Jennifer A Moynihan²,3, Candela Muriel'1, David Dowling ${ }^{4}$, Fergal O'Gara ${ }^{2,3}$, Marta Martín ${ }^{1}$ and Rafael Rivilla ${ }^{1 *}$

\begin{abstract}
Background: Pseudomonas fluorescens F113 is a plant growth-promoting rhizobacterium (PGPR) isolated from the sugar-beet rhizosphere. This bacterium has been extensively studied as a model strain for genetic regulation of secondary metabolite production in P. fluorescens, as a candidate biocontrol agent against phytopathogens, and as a heterologous host for expression of genes with biotechnological application. The F113 genome sequence and annotation has been recently reported.
\end{abstract}

Results: Comparative analysis of 50 genome sequences of strains belonging to the $P$. fluorescens group has revealed the existence of five distinct subgroups. F113 belongs to subgroup I, which is mostly composed of strains classified as $P$. brassicacearum. The core genome of these five strains is highly conserved and represents approximately $76 \%$ of the protein-coding genes in any given genome. Despite this strong conservation, F113 also contains a large number of unique protein-coding genes that encode traits potentially involved in the rhizocompetence of this strain. These features include protein coding genes required for denitrification, diterpenoids catabolism, motility and chemotaxis, protein secretion and production of antimicrobial compounds and insect toxins.

Conclusions: The genome of P. fluorescens F113 is composed of numerous protein-coding genes, not usually found together in previously sequenced genomes, which are potentially decisive during the colonisation of the rhizosphere and/or interaction with other soil organisms. This includes genes encoding proteins involved in the production of a second flagellar apparatus, the use of abietic acid as a growth substrate, the complete denitrification pathway, the possible production of a macrolide antibiotic and the assembly of multiple protein secretion systems.

\footnotetext{
* Correspondence: rafael.rivilla@uam.es

${ }^{\dagger}$ Equal contributors

'Departamento de Biología, Facultad de Ciencias, Universidad Autónoma de Madrid, c/Darwin, 2, Madrid 28049, Spain

Full list of author information is available at the end of the article
} 


\section{Background}

Pseudomonas fluorescens F113 is a PGPR strain isolated from the sugar-beet rhizosphere in Ireland [1]. Initially this strain was selected and studied because of its capacity to inhibit growth of a range of phytopathogenic bacteria, fungi, oomycetes and nematodes including Pectobacterium caratovorum [2], Fusarium oxysporum [3], Pythium ultimum [4] and Globodera spp. [5]. This antimicrobial capacity is strongly linked to the production of a secondary metabolite, 2,4-diacetylphloroglucinol (DAPG) $[4,6]$, and renders the strain a candidate bio control microorganism for agrobiotech applications. The biosynthetic and regulatory genes required for the synthesis of this polyketide are located in an $8 \mathrm{~kb}$ cluster of nine protein-coding genes that are highly conserved in other DAPG-producing P. fluorescens but completely absent from non-producing strains $[7,8]$. In addition, $P$. fluorescens F113 is an excellent rhizosphere coloniser of different plant species including wheat [9], alfalfa [10], and willow [11,12]. For that reason, F113 is widely used as a model for studying rhizosphere colonization $[13,14]$. Several studies have sought to take advantage of this colonising ability by developing novel genetically modified derivatives with biotechnological traits, for example the capacity to degrade polychlorinated biphenyls and other environmental pollutants $[11,15]$.

The Pseudomonas genus is composed of more than 100 species, which have been divided by multilocus sequence analysis (MLSA) into nine major groups: P. fluorescens, $P$. syringae, $P$. lutea, P. putida, P. anguilliseptica, P. straminea, $P$. aeruginosa, $P$. oleovorans and $P$. stutzeri [16]. Some of these groups are themselves composed of different subgroups containing multiple species. For instance, the $P$. fluorescens group can be further divided into nine subgroups [16]. The number of species present in each of these subgroups is somewhat difficult to assess since novel formal species, such as $P$. protegens [17], are frequently described. A number of genome sequences for strains belonging to the P. fluorescens group have been recently obtained (Additional file 1). The initial comparative genomic analysis of the three first complete genome sequences of strains belonging to the $P$. fluorescens group has highlighted a large number of strain-specific genes [18]. Therefore, it has been proposed that the sequenced strains belong to a complex of species rather than to a single species [19]. More recently, a comparative genomics analysis performed on 10 genome sequences of strains belonging to the $P$. fluorescens group has highlighted three main subclades [20].

Here we present an analysis of the genome sequence of P. fluorescens F113 [21] compared to 49 other complete and draft genomes of strains classified as Pseudomonas spp., P. brassicacearum, P. fluorescens, P. protegens, $P$. mandelii, P. chlororaphis, P. tolaasii and P. extremaustralis.
The genome of $P$. fluorescens F113 [21] is composed of a single circular chromosome of $6,845,832$ bp with an average $\mathrm{G}+\mathrm{C}$ content of $60.8 \%$ and an overall coding density of $86.7 \%$ (Additional file 2). Following automatic annotation and subsequent manual curation, a total of 5862 protein-coding sequences, nine ncRNAs, five rRNA operons and 66 tRNA loci were detected in the genome of this strain. The F113 genome contains a variety of protein-coding genes that appear relevant for thriving in the rhizosphere environment. This includes unusual metabolic adaptations within the P. fluorescens species, protein-coding genes related to motility, genes encoding putative toxins targeted to diverse organisms and a very large number of protein-coding genes involved in the assembly of different secretion systems. The distribution of these traits in other strains belonging to the P. fluorescens group as well as the functionality of several of these genes are described in this manuscript.

\section{Results and discussion}

\section{P.fluorescens F113 phylogenomics comparison}

In order to determine the phylogenetic relationship of F113 to other pseudomonads, a phylogenomic analysis of 162 Pseudomonas genomes and draft genomes available at the time of this writing was performed with the composition vector method [22]. The phylogenomics tree generated with such approach (Figure 1A) is mostly congruent with previous concatenated sequence trees obtained in different MLSA analyses [16,20,23]; and clearly highlighted the need to re-evaluate the taxonomic status of species belonging to the P. fluorescens group [18]. Compared to other trees, the major difference is the phylogenetic position of $P$. putida and $P$. syringae with respect to the $P$. fluorescens group. However the distances shown here for this two species to the parent node are very small and differences could be due to the different methods used. Fifty strains (Additional file 1) previously classified as P. fluorescens (including F113), P. brassicacearum, $P$. protegens, $P$. mandelii, P. chlororaphis, P. tolaasii, $P$. extremaustralis and Pseudomonas spp. formed a single cluster which branched significantly deeper than other clusters that represent defined species such as $P$. aeruginosa or $P$. syringae. Detailed phylogenomic analysis of the $P$. fluorescens group revealed the presence of at least five subgroups with strains previously classified as P. fluorescens, interspersed with strains classified in other species (Figure 1B). The analysis of the whole 50 strains ORFome, represented as a vector of 6 mer peptide frecuencies, has allowed us to increase the number of $P$. fluorescens subgroups from three [20] to five. It is likely that some of these subclusters may represent different species, especially considering that all of these subclusters branch above a 0.16 dissimilarity threshold, a value enough to discriminate recognized species within the genus Pseudomonas. 


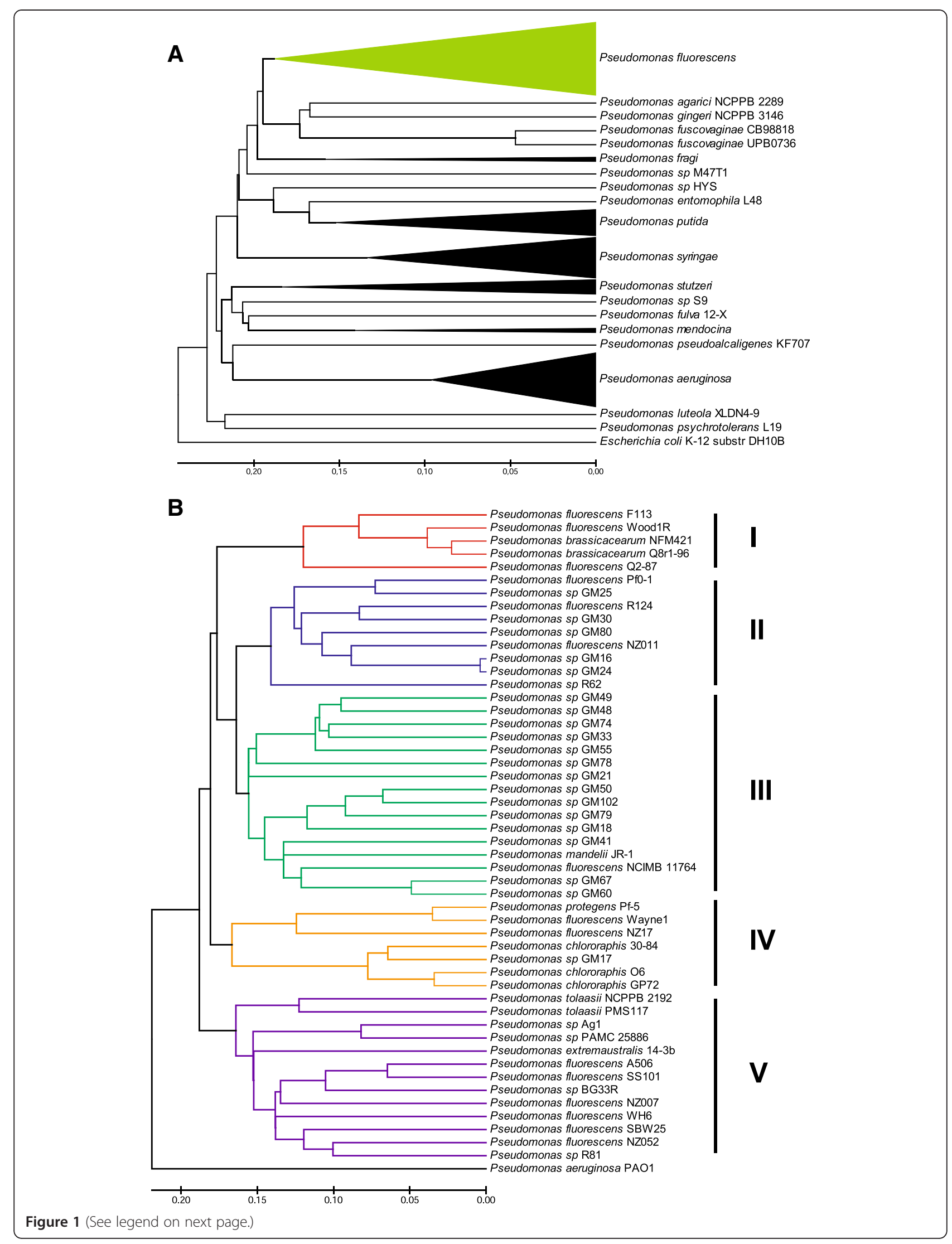


(See figure on previous page.)

Figure 1 Pseudomonas spp phylogenomic analysis. (A) Whole-genome based phylogenomic tree by using composition vector approach. Strains belonging to the $P$. fluorescens group are collapsed within the green branch. (B) Phylogenomic tree of strains in the $P$. fluorescens group. Subgroups I to $V$ as described in this work, are highlighted in different colours. Scale shows kmer distribution divergence. Completed and draft genomes of the used $P$. fluorescens strains are listed in Additional file 1.

Subgroup I contains F113 together with strains classified as Pseudomonas brassicacearum, including the complete genome sequence of NFM421 [24]. Subgroup II contains the sequenced strain $P$. fluorescens $\mathrm{PfO}-1$ and other strains classified either as P. fluorescens or Pseudomonas spp. Although, these two subgroups were initially described as one subclade by Loper et al. [20], the separation between these two subgroups is supported by a branching above 0.16 dissimilarity. Subgroup III includes P. fluorescens NCIMB 11764, P. mandelii JR-1 and several unclassified pseudomonads, which were not analysed in previous studies. Subgroup IV contains $P$. protegens Pf-5, all the $P$. chlororaphis strains, $P$. fluorescens strains Wayne1 and NZ17 and one unclassified pseudomonad. This subgroup is congruent with subcluster 1 [20]. Finally, subgroup V contains P. fluorescens strains SBW25, WH6, A506, SS101 NZ007 and NZ052, together with $P$. tolaasii strains, $P$. extremaustralis and four unclassified pseudomonads. This subgroup corresponds to subcluster 3 [20].

The genome sequence of strain F113 was then aligned with its closest fully sequenced relatives, $P$. brassiccacearum NFM421 and $P$. fluorescens Pf0-1 (Figure 2A). This alignment shows that F113 genome is much more similar to the NFM421 than to the PfO-1 genome, supporting the subclustering described above. It also shows that the major difference between the F113 and NFM421 genomes is a large inversion in the distal part of the genome, opposite to the replication origin. It is interesting to note that both strains were isolated from a similar ecosystem, the rhizosphere of a crop although in different hemispheres and that both strains share similarities such as the occurrence of phase variation during rhizosphere colonization, the presence of denitrification genes (see below) and the presence of three chemotaxis gene clusters (see below).

The presence of the F113 orthologous coding sequences (CDSs) in the 50 genomes sequences from the P. fluorescens group was assessed using OrthoMCL [25]. Following this analysis, the core genome of the $P$. fluorescens group is composed of 2003 orthologous CDSs present in all the fifty strains examined. Unsurprisingly, the size of the core genome is smaller in comparison to previous analysis performed with 3 (3642 orthologous CDSs) and 10 (2789 orthologous CDSs) genome sequences $[18,20]$. The core genome of the $P$. fluorescens subgroup $\mathrm{I}$ is composed of 4407 orthologous CDS (Figure 2B), which represents approximately $76 \%$ of the whole predicted proteome. In addition 344 orthologous CDSs $(5.9 \%$ of the predicted proteome) found in the F113 genome are not present in any other genome of strains within this subgroup. These 344 CDSs were subjected to BLASTP analysis against the non-redundant (nr) NCBI database (Additional file 3). Closest relatives of these unique protein-coding genes are mostly found in other gamma-proteobacterial genomes, including other Pseudomonas species, and could be involved in important functions relevant for rhizosphere fitness (discussed in the sections below).

\section{The F113 genome encodes important traits involved in rhizocompetence}

A number of plant-associated bacteria, including Pseudomonas spp. [26,27] and Azospirillum brasilense [28], are able to use nitrogen oxides as alternative electrons acceptors under oxygen limiting conditions, a process called denitrification. Denitrification has been shown to play a role in rhizosphere colonization, since mutants of $P$. fluorescens impaired in nitrate or nitrite reductases are deficient in the colonization of the rhizosphere [26,29,30]. Furthermore, it has been shown that denitrification is statistically associated with rhizosphere competence in rhizosphere isolated fluorescent pseudomonads [31]. The F113 genome encodes approximately 50 proteins involved in denitrification. These genes are organized in four clusters on the chromosome (Figure 3A). The first cluster (PSF113_3777-3782) contains the narK1K2GHJI genes, which encode the membrane-bound nitrate reductase. The sensor-response regulator NarL-NarX and the transcriptional regulator DnrS are encoded upstream of the nar genes. The periplasmic (Nap) and the assimilatory nitrate reductase (Nas) are also present in the genome of F113 (PSF113_3040-3044 and PSF113_1771, respectively). The second cluster (PSF113_3744-3766) is composed of the nir and nor 1 genes encoding nitrite and nitric oxide reductase, respectively. The third cluster (PSF113_2993-2998) contains the nos 1 genes that encode the nitrous oxide reductase. All these genes showed highest homology with denitrification genes in different pseudomonads (Additional file 4). Finally the last cluster (PSF113_3422PSF113_3432) contains the nos 2 and nor 2 genes. Although the nos 2 genes showed homology (73-85\% identity) with the nos 1 genes, the nor 2 genes are quite divergent to nor 1 genes and showed higher homology with genes encoded in Acidovorax and several Enterobacteriaceae. It is interesting to note that the $\sigma 54$-transcriptional activator NorR2 (PSF113_3436) is encoded in the downstream region of the nos2-nor2 cluster, which suggests that nos1nor 1 and nos 2 nor 2 genes might be independently regulated. In 


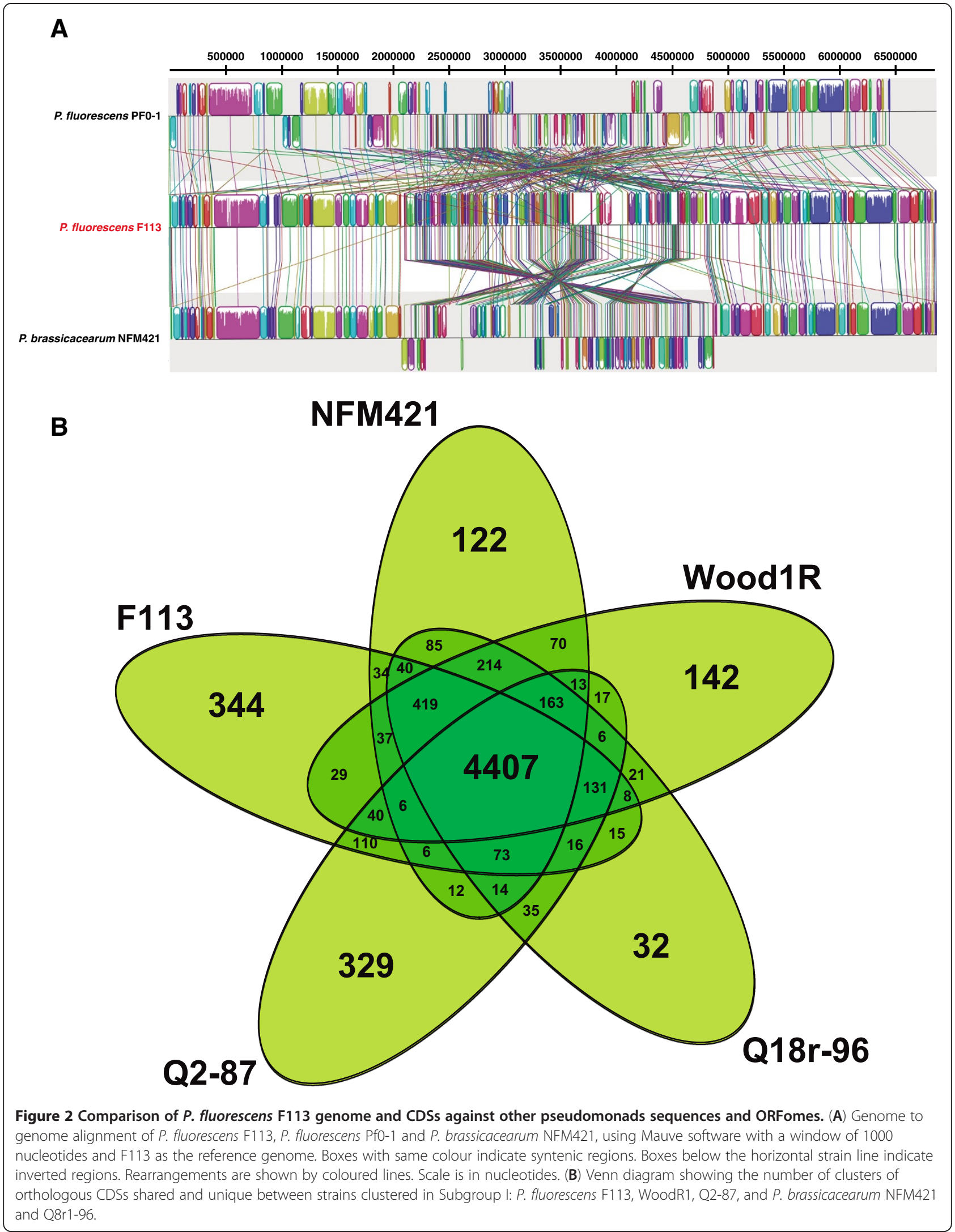




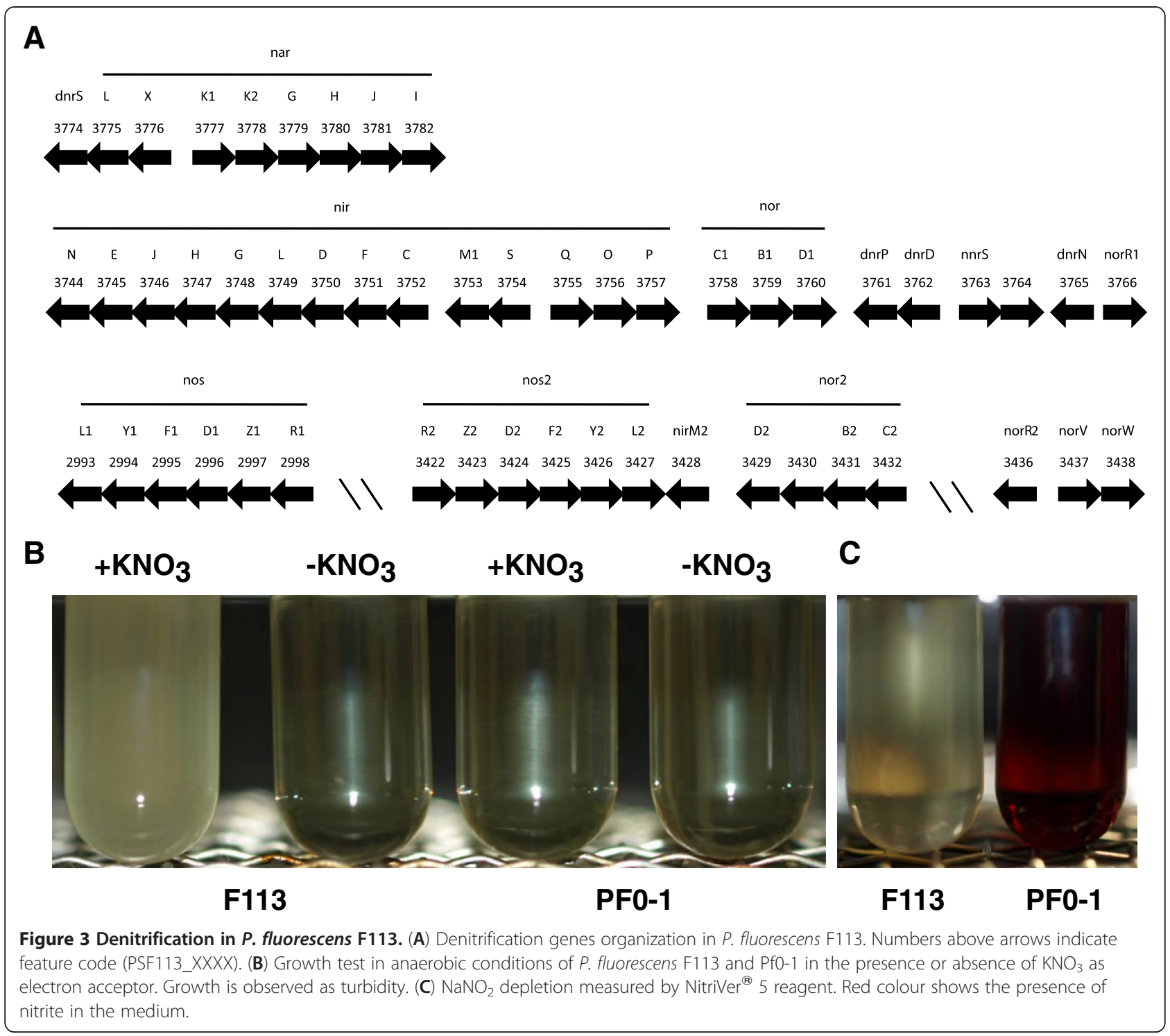

order to test the functionality of these denitrification genes, the growth of F113 under anaerobic conditions was compared to the growth of Pf0-1, which does not contain denitrification genes. While Pf0-1 did not grow under these conditions, F113 was able to grow anaerobically using nitrate and nitrite as electron acceptors (Figure 3B). Furthermore, a total depletion of nitrite was observed after $48 \mathrm{~h}$ of growth (Figure $3 \mathrm{C}$ ). These results together with the presence of two copies of the nos genes, strongly indicate that F113 is capable of full denitrification. The duplication of genes encoding nitric oxide reductase and nitrous oxide reductase might be related to high denitrification rates, as has been shown for a Bacillus strain that contains two different copies of the nos $Z$ gene and showed high amounts of $\mathrm{N}_{2}$ production [32]. The presence of denitrification genes was analyzed in the fifty strains forming the $P$. fluorescens group
(Additional file 4). While all strains of subgroup I contained a complete denitrification pathway, none of the strains of subgroup II possessed denitrification genes, which further support the distinction between subgroup I and II. Interestingly some denitrification genes are present in few strains belonging to subgroups III, IV and V, which might indicate horizontal gene transfer. Whereas nor 2 genes were only present F113 and NFM421, nos2 genes were systematically found in strains harbouring the nos 1 genes.

Another metabolic adaption is the potential degradation of aromatic diterpenes encoded in the F113 genome. Aromatic diterpenes are tricyclic resin acids naturally produced by trees and include abietic, dehydroabietic and palustric acids. Bacteria that harbor the dit genes can grow in these substrates as the sole carbon and energy source [33]. These genes have been found in several Proteobacteria such as Burkholderia, Cupriavidus and 
Pseudomonas [33]. Among Pseudomonas, dit genes have been found in P. abietaniphila [34], P. diterpeniphila [35] and in P. aeruginosa strain PA2192 [36]. F113 chromosome harbors a $65 \mathrm{~Kb}$ genetic island containing the dit genes (PSF113_3386-PSF113_3413). This region is contiguous to the nos2-nor 2 cluster and has a gene organization similar to the genetic island found in $P$. aeruginosa PA2192, although in this strain certain dit genes are duplicated and the genomic island is $115 \mathrm{~Kb}$ long [36]. Growth of F113 on abietic acid was compared with growth of Pf0-1. After twenty days, growth was observed for F113 but not for Pf0-1, suggesting that dit genes in F113 are functional.

\section{Plant growth-promoting traits}

Previous studies have shown that P. fluorescens F113 is capable of inorganic phosphate solubilisation through the extracellular production of gluconic acid $[37,38]$. Moreover, F113 seems capable of mineralizing insoluble organic phosphates pool by the production of specific enzymes, such as the homologues of the alkaline phosphatases PhoD (PSF113_0888) and PhoX (PSF113_5402) of P. fluorescens Pf0-1 [39] and a beta-propeller phytase (PSF113_2886) [40]. Altogether, these traits could contribute to mobilization of insoluble soil phosphate into bioavailable forms that can be taken up by the plant root.

ACC deaminase activity in F113 has been reported previously [41] and analysis of the genome sequence indicates that PSF113_3500 (acdS) encodes a 1-aminocyclopropanecarboxylate (ACC) deaminase. ACC deaminase (EC 4.1.99.4) catalyses the degradation of the ethylene precursor, ACC, into ammonium and $\alpha$-ketobutyrate (2-oxobutanoic acid) and has been linked to plant growth promotion activity in rhizosphere microorganisms [42]. The activity of the AcdS enzyme in F113 is $4.783 \mu \mathrm{M} \mathrm{mg}^{-1}$ protein $\mathrm{hr}^{-1}$, almost twice the activity of Enterobacter UW4 [43]. The expression of acdS is probably regulated by the LRP-like transcriptional regulator $a c d R$, which is located upstream of $a c d S$.

\section{Motility and chemotaxis}

Like all Pseudomonas strains, F113 genome encodes genes for the synthesis of polar flagella distributed in three clusters. Several of these genes in F113 have been previously analyzed $[44,45]$ and regulation of flagella synthesis requires the master regulatory gene fleQ [46]. Besides these genes, F113 chromosome harbors another $41 \mathrm{~kb}$ flagella locus containing $40 \mathrm{CDSs}$ (PSF113_0738-PSF113_0782), which is not present in any other Pseudomonas genome, with the exception of $P$. extremaustralis (Figure 4A). Conversely to the operons encoding flagellar genes in pseudomonads, this region contains an $f h D C$ operon, encoding master regulatory proteins of flagella synthesis in other gammaproteobacteria such as enterobacteria and Azotobacter. The
40 ORFs showed high homology to flagellar genes of Azotobacter vinelandii, a soil bacterium phylogenetically related to the genus Pseudomonas, but producing a different type of flagella, which are peritrichous, instead of the typical single or double polar flagella produced by pseudomonads. The region also showed synteny with the flagellar genes of $A$. vinelandii (Figure 4A). The $A$. vinelandii chromosome harbors flagellar genes in two clusters, I and II. Genes in cluster I are conserved in the same order in the $41 \mathrm{~Kb}$ region in the F113 chromosome. Cluster II in A. vinelandii is located 416 $\mathrm{Kb}$ downstream of Cluster I. A reduced version of this region and lacking 12 ORFs is located in an inverted orientation adjacent to Cluster I in the F113 chromosome. All the genes present in $A$. vinelandii clusters, but absent in the F113 genome, encode chemotaxis proteins such as CheZ, CheY, and CheB or proteins that are not essential for flagella synthesis, such as RfbC, RfbG and RfbF. Ectopic expression of $f l h D C$ in F113 increased swimming motility (Figure 4B) and resulted in hyperflagellation with multiple polar flagella (data not shown). These results indicate that F113 can produce the second type flagella, and that these flagella are functional. In Rhodobacter sphaeroides, a second acquired flagellum is also functional and coexists with the endogenous flagellar system [47]. In this case, as in F113, both flagella were polar. Although flagella whose synthesis is regulated by the master regulatory genes $f l h D C$ are generally peritrichous, regulation of polar flagella by this system has also been observed in Burkholderia glumae [48], indicating that $f l h D C$ regulation does not imply peritrichous flagellation.

The F113 genome encodes five chemotaxis-like systems: Wsp, Chp, Che1, Che2 and Che3 (Additional file 5). The Wsp system (PSF113_1084-PSF113_1090) is implicated in regulation of motility and biofilm formation in F113 [13,49] and other P. fluorescens strains [50,51]. The Chp system (PSF113_5524-PSF113_5525) is located in the immediate vicinity of to pil genes and has been shown to control twitching motility in Pseudomonas aeruginosa [52]. Besides, the F113 genome encodes three Che systems (Figure 5). Che1 (PSF113_1586-PSF113_1594, PSF113_4455 and PSF113_4456) is located in the vicinity of proteincoding genes involved in the assembly of the endogenous flagellum. Mutation of the cheA1 gene in F113 resulted in impaired motility and rhizosphere colonization [53] indicating that this system participates in chemotactic motility. It is interesting to note that no genes encoding methyl accepting chemotactic sensors (MCPs) are genetically linked to this system, although more than thirty ORFs predicted to encode MCP-like proteins are scattered in the F113 genome. The Che2 (PSF113_2284-PSF113_2292) and Che3 (PSF113_3554-PSF113_3563) systems are present in a restricted number of strains of the $P$. fluorescens group (Additional file 5). The Che 2 genes are only present in all 


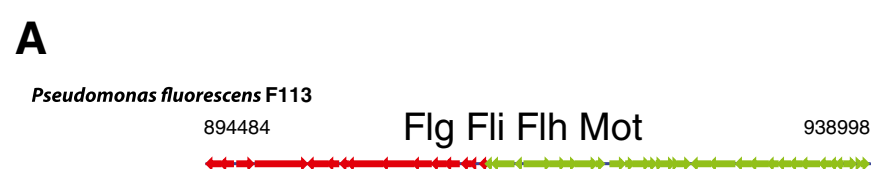

Azotobacter vinelandii DJ

$2396274 \quad$ Flg Fli Flh Mot $24267912843124 \quad$ Mot Fli Flh

B

F113 WT

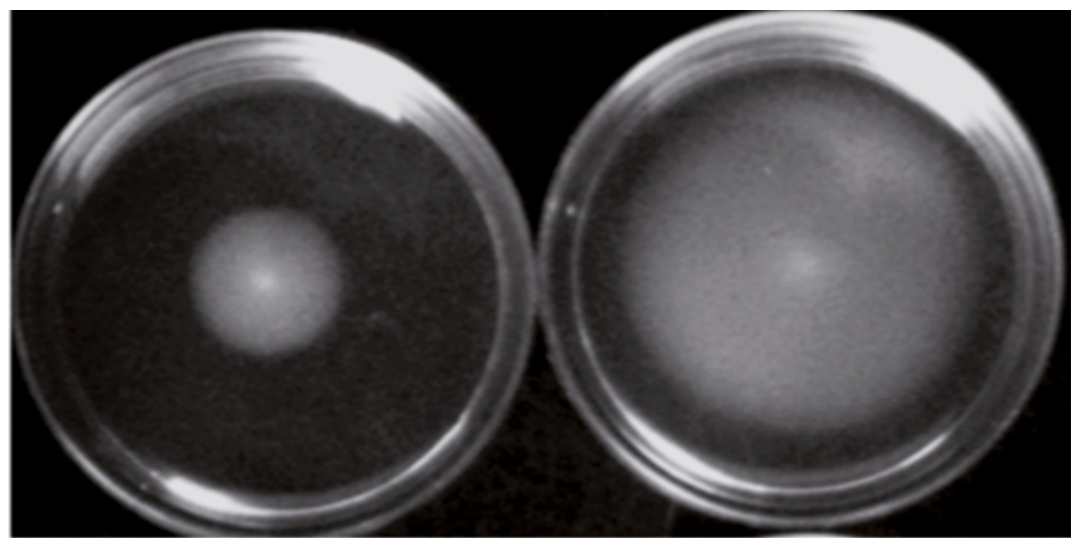

Figure 4 F113 produces a second flagellar apparatus. (A) Gene cluster organization of P. fluorescens F113 second flagellum compared to Azotobacter vinelandii DJ. Flagellar genes in A. vinelandii are located in two separated clusters compared to the single cluster in F113. ORFs arrows are at scale. Numbers indicate chromosome coordinates in both strains. (B) Swimming motility of P. fluorescens F113 wild type and a modified strain overexpressing the second flagellum master regulator flhDC operon. Increased motility is shown by a larger halo after 18 h. incubation.

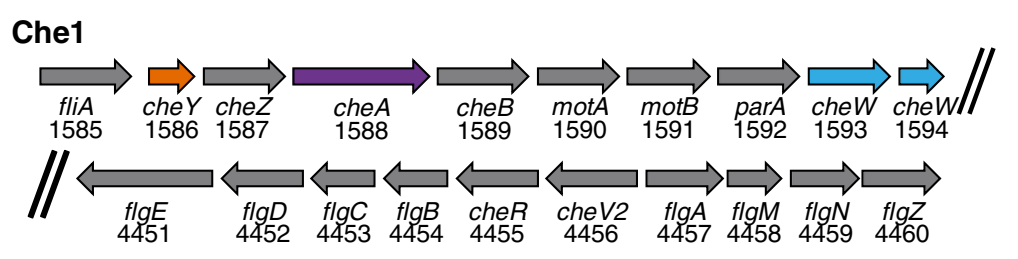

\section{Che2}

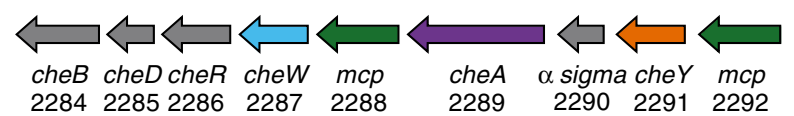

\section{Che3}

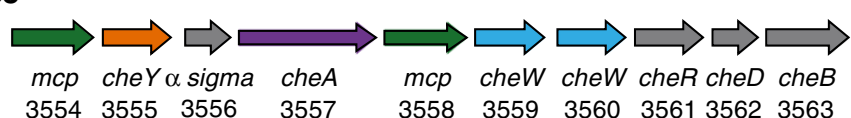

Figure 5 The F113 genome contains three groups of che genes. Genomic organisation of the Che regions in P. fluorescens F113. The Che 1 genes are organized in two genomic regions. Arrows with the same colour correspond to paralogues. Numbers below arrows indicate feature code (PSF113_XXXX). 
strains of Subgroup I and three strains of the Subgroup V. The Che 3 genes are present only in three strains of Subgroup I: F113, NFM421 and Wood 1. Both Che 2 and Che 3 systems harbor two genes putatively encoding MCPs, suggesting that these systems might be implicated in specialized functions. This diversity of chemotaxis systems, as well as the production of a second type flagellum, highlights the importance of motility for F113. It is important to note that chemotaxis and motility mutants are among the most affected mutants in competitive rhizosphere colonization $[44,53]$ and that the rhizospheric environment selects for hypermotile phenotypic variants $[14,54]$ that are frequently hypercompetitive [14]. It also raises interesting questions about which chemotaxis systems are used by the second type flagellum and about motility under different physiological condition, for example anaerobic growth using nitrate or nitrite as electron acceptors.

\section{Protein and macromolecule secretion}

Gram negative bacteria rely on several secretion systems to influence their environment by translocating protein and DNA into neighbouring cells and the extracellular milieu. These secretion systems can range from simple transporters to multi-component complexes and have been classified into six types: from type I through type VI secretion system (T1SS-T6SS) [55]. The genome of F113 contains a wide variety of secretion systems, which include six T1SSs, two T2SSs, two T3SSs, one T4SS, five T5aSSs, four T5bSS, one T5dSS and three T6SSss (Table 1).

\section{T2SSS}

T2SS is the most ubiquitous secretion system used by Gram negative bacteria to secrete extracellular protein. Therefore, T2SS is well-conserved and involves a set of

Table 1 The full repertoire of secretion systems of $P$. fluorescens F113

\begin{tabular}{|c|c|c|c|}
\hline Secretion system & Phylogenetic cluster & Locus & Putative substrate \\
\hline \multirow[t]{8}{*}{ T1SS } & & PSF113_0209-0211 & PSF113_0208 \\
\hline & & opmH (PSF113_0530*) & \\
\hline & & PSF113_1508-1510 & PSF113_1511 \\
\hline & & PSF113_2734-2736 & PSF113_2737 \\
\hline & & aprDEF (PSF113_2945-2947) & aprA (PSF113_2949), aprl (PSF113_2948), lipA (PSF113_2944) \\
\hline & & PSF113_3005-3007 & psmE (PSF113_3004) \\
\hline & & PSF113_3055-3056* & \\
\hline & & PSF113_3303-3305 & \\
\hline \multirow[t]{2}{*}{ T2SS } & $X_{c p}$ & $\begin{array}{l}\text { xсpP-Z (PSF113_0437-0447), } \\
x с P A \text { (PSF113_5006) }\end{array}$ & PSF113_0435, PSF113_0610, PSF113_2337, PSF113_3279 \\
\hline & $\mathrm{Hxc}$ & $h \times c P-Z$ (PSF113_3690-3700) & psp (PSF113_3701) \\
\hline \multirow[t]{2}{*}{ T3SS } & SPI-I & invF-orgB (PSF113_1778-1801) & PSF113_1802 \\
\hline & Hrp1 & rspS-rspL (PSF113_5585-5610) & $\begin{array}{l}\text { ropAA-1 (PSF113_1126), ropAA-2 (PSF113_3486), ropB } \\
\text { (PSF113_5598), ropM (PSF113_5616) }\end{array}$ \\
\hline T4SS & Gl-like & PSF113_3314-3334 & \\
\hline \multirow[t]{5}{*}{ T5aSS } & & PSF113_2779 & \\
\hline & & PSF113_2780 & \\
\hline & & PSF113_4399 & \\
\hline & & estA (PSF113_5339) & \\
\hline & & PSF113_5848 & \\
\hline \multirow[t]{4}{*}{ T5bSS } & & PSF113_0792-0793 & \\
\hline & & PSF113_1489-1490 & \\
\hline & & PSF113_4466-4468 & \\
\hline & & PSF113_2623-PSF113_3702 & \\
\hline T5dSS & & plpD (PSF113_1517) & \\
\hline \multirow[t]{3}{*}{ T6SS } & । & HSI-II (PSF113_5815-5833) & $\begin{array}{l}\text { hcp2 (PSF113_1976), PSF113_0495, PSF113_0666, } \\
\text { PSF113_3144, PSF113_3904 }\end{array}$ \\
\hline & III & HSI-I (PSF113_5785-5808) & vgrG1b (PSF113_2885) \\
\hline & IVA & HSI-III (PSF113_2407-2422) & \\
\hline
\end{tabular}


11 to 12 proteins [56]. According to XcpR phylogenetic analysis, Pseudomonas T2SSs could be divided in two main clusters: Xcp (extracellular protein), and Hpx (homologue to Xcp) (Additional files 6 and 7). Two complete T2SSs related to the Xcp cluster (PSF113_0437-0447) and to the Hxc cluster (PSF113_3690-3700) are present in the genome of F113 (Additional file 7). The genetic organization of the Hxc cluster of F113 is highly similar with the Hxc cluster of P. aeruginosa PAO1 and P. fluorescens SBW25 [57,58]. Moreover, a predicted ORF sharing $74 \%$ and $72 \%$ identity at the amino acid level with the Hxc substrate Psp of $P$. fluorescens SBW25 [58] and DinG of P. aeruginosa MDR1 [59] is located immediately downstream of the Hxc locus, which suggest that this protein could possibly be secreted by the Hxc secretion system of F113. The second T2SS locus of F113 is identical to the second Xcp of P. aeruginosa PA7, which is present on the genomic island RGP69 (PSPA7_1407-1420) [60]. Based on homologies with known Xcp effectors, it seems that at least four predicted F113 proteins could potentially be Xcp substrates (PSF113_0435, PSF113_0610, PSF113_2337 and PSF113_3279).

\section{T3SSs}

T3SS is a nanomachine composed of approximately 25 proteins [61], which has evolved into seven different families: Ysc, Hrp1, Hrp2, SPI-1, SPI-2, Rhizobiaceae and Chamydia [62,63]. The distribution of T3SS loci in complete or draft Pseudomonas genome sequences was investigated using the following ORFs PA1703, PSPTO_1402, PSPPH_2520 and PSF113_1781 (COG4789) as queries in sequential BLASTp and TBLASTn searches. Four T3SS phylogenetic families, Ysc, SPI-1, Hrp1 and Rhizobia are encoded in the different Pseudomonas chromosomes (Additional file 8). While Ysc is only found in $P$. aeruginosa, the other T3SS phylogenetic families are distributed across different Pseudomonas groups. For example, strains belonging to the $P$. fluorescens group can contain SPI-1, Hrp1 or Rhizobia T3SS.

Although the Hrp1 locus is present in approximately 40\% of the P. fluorescens genomes (Additional file 6), two distinct sub-families are found in different chromosomal locations [64]. The Hrp1 locus (PSF113_5585-5616) encoded in the F113 chromosome is, perhaps unsurprisingly, closely related to Hrp1 of P. fluorescens Q8r1-96 [64], Q2-87 [20], Wood1R [65] and P. brassicacearum NFM421 [24]. The predicted T3Es RopAA1, RopB and RopM reported by Mavrodi et al. [64] are also encoded in the genome of F113, Q2-87, Wood1R and NFM421. In addition a putative paralogue of RopAA1, called here RopAA2 (PSF113_3486), is found in all these strains.

In comparison to Hrp1, the SPI-1 phylogenetic family is less abundant in the Pseudomonas genome sequences (Additional file 6). Comparative genomics analysis of SPI-1 clusters belonging to strains belonging to the $P$. fluorescens group, revealed that these loci are found in the same chromosomal location, flanked by the genes nasT and pyrD. In F113, however, the SPI-1 cluster is flanked by nasT (PSF113_1777) and soxR (PSF113_1805). This is due to genome rearrangement, probably caused by IS3-family transposases (PSF113_1803-1804 and PSF113_4042-4043). Examination of other P. fluorescens genomes indicated that the genes invG, iagB and pseudogene related to hilA are present at the same chromosomal location in strains PAMC 25886 [66], Ag1 [67], 14-3 [68], WH6 [69], SBW25 [18], R81 [70], A506, BG33R, SS101 [20], NZ007, NZ052 and PMS117. Interestingly all these strains belong to subgroup $\mathrm{V}$ of the $P$. fluorescens group, which suggest that the SPI-1 cluster was lost before speciation of this sub-clade. While the SPI-1 cluster is conserved across strains belonging to the sub-clade composed of UPB0736 [71], CB98818, NCPPB 3146 and NCPPB 2289; its random distribution across the other strains of the $P$. fluorescens group could suggest an acquisition by horizontal gene transfer. Investigation of the average GC content of the SPI-1 clusters did, however, not show any shift in comparison to the average content of the genome examined (Additional file 9). This is not the case with the SPI-1 cluster of two strains belonging to the P. putida group, which have an atypical GC content, therefore suggesting horizontal gene transfer acquisition.

\section{T6SSs}

The Type VI secretion machinery is the product of approximately 15 conserved genes which are generally found together inside a genomic locus [72]. T6SS are widespread in Proteobacteria, particularly among gammaProteobacteria and have been classified into five distinct phylogenetic clusters (from 1 to 5) [73]. However a recent comparative genomic analysis has further divided the cluster 4 into $4 \mathrm{~A}$ and $4 \mathrm{~B}$ [74]. P. aeruginosa possesses three different loci named HSI-I (cluster 3), II (cluster 1) and III (cluster 4A), which perform different functions. Whereas HSI-I is be involved in inter-bacterial interactions through secretion of Tse1, Tse 2 and Tse3 [75-77], HSI-II and III could be linked to virulence towards animals and plants [78,79]. To date, strains belonging to the P. fluorescens group possess between one to four T6SSs per genome, which belong to cluster 1 to 4B (Additional files 6 and 10). F113 contains the three most common T6SS phylogenetic clusters, which are related to the HSI loci. Moreover, in this strain the two loci HSI-I (PSF113_5785-5807) and HSI-II (PSF113_5815-PSF113_5830) are located besides each other in a tandem arrangement, which is an uncommon feature of T6SS. In addition to the T6SSs loci, most bacterial strains encode additional $\operatorname{vgrG}$ and $h c p$ genes that encode extracellular structural components of the secretion apparatus, which are encoded elsewhere in the genome [80]. From the eight VgrGs and three Hcps 
encoded in the F113 genome, five VgrGs and one Hcp proteins are located outside T6SS loci [74].

\section{Other virulence and niche adaption traits}

Different strains of $P$. fluorescens produce a set of secondary metabolites with antifungal and antibacterial properties [81]. These metabolites are important for competition and survival in the rhizosphere and are the basis of biocontrol activities. F113 genome carries gene responsible for siderophores synthesis, including pyoverdine [2] and pyridine-2,6-bis-thiocarboxylic acid [82]. Moreover F113 produces antimicrobial compounds unrelated to siderophores such as hydrogen cyanide [83] and DAPG [4] (Table 2).

Besides the genes encoding the enzymes required for the biosynthesis of these compounds, the F113 genome contains a cluster of genes (PSF113_3657- PSF113_3666) that is likely to encode genes for the synthesis of an unknown antibiotic. This $40 \mathrm{~Kb}$ cluster encodes four polyketide synthase modules, one dehydratase, one transacylase, one transferase, one isochorismatase and one transport protein (Figure 6). There are not homologous genes to these in the genus Pseudomonas and the closest homologues (39-42\% homology with coverage over $90 \%$ of the sequence) are found in genes responsible of the synthesis of macrolide antibiotics from different Streptomyces species, including the lankacidin production cluster of Streptomyces rochei [84]. The lankacidin $(l k c)$ gene cluster of $S$. rochei is composed of 15 ORFs ( $l k c A B C D E F G H I J K L M N O$ ), which encode a polyketide synthase (PKS)/nonribosomal peptide synthetase (NRPS) hybrid gene $(l k c A)$, type I PKS genes, and the essential cluster for the lankacidin production, pyrroloquinoline quinone (PQQ) biosynthetic genes $(l k c K-l k c O)[85,86]$. The presence of this cluster in other genomes was therefore investigated by comparative genomic analysis. Besides Streptomyces rochei plasmid pSLA2-L and P. fluorescens F113 the $l k c$ cluster was only found in one additional genome: Hahella chejuensis KCTC 2396. In P. fluorescens F113, the PQQ genes, which are crucial for lankacidin production in Streptomyces rochei [85] are found outside the $l k c$ gene cluster [37]. The possible production of this unknown antibiotic is likely to contribute to rhizosphere and soil competence.

It has been shown that $P$. fluorescens strains can kill nematodes [5] and are pathogenic to insects [87]. Preliminary results show that F113 is toxic towards the model nematode Caenorhabditis elegans and the protozoan Acanthamoeba polyphaga. F113 repels these bacteriovores and/or prevents their growth feeding on this strain (our unpublished data). In addition, F113 kills the model insect Galleria mellonella, after $48 \mathrm{~h}$ of infection with a dose of $10^{8}$ bacteria per larvae (our unpublished data). These features could be explained by the production of putative insecticidal toxins (PSF113_0731 and PSF113_0732), which are also found in Pseudomonas strains NFM421 and Pf0-1 and in other bacterial species such as Yersinia enterocolitica [88]. In addition, a number of other putative toxins and virulence factors are present in $P$. fluorescens F113 genome including 16 predicted hemolysin/haemagglutinins, nine adhesin or agglutination proteins, two RTX toxins, seven Rhs-family proteins and eight YDrepeat-containing proteins.

\section{ICE and prophage elements}

Analysis of the F113 genome has revealed the presence of one putative integrative conjugative element (ICE) of $175 \mathrm{~kb}$ containing 158 ORFs located downstream a tRNA-glycine (PSF113_3287). This putative bacteriophagederived mobile genetic element is surrounded by attF and $a t t R$ sites (TTGGAGCGGGAAACGAGACTCG) and possesses protein-coding genes required for excision and integration (PSF113_3288-3301). The mobilization of the ICE could be mediated by a GI-T4SS (PSF113_3314-3334), which is responsible for the formation of the conjugative pilus and the resulting conjugative transfer [89]. However, it remains to be determined whether this GI-T4SS is functional since a conserved T4SS component is disrupted by a IS66 transposase (PSF113_3325-3327). In addition to protein-coding genes involved in the integration and transfer of this hypothetical ICE, the cargo genes are related to T1SS (PSF113_3303-3305) dit cluster (PSF113_3356-3417) and nos2nor2 (PSF113_3422-3438), described above.

Table 2 Biosynthetic clusters involved in secondary metabolism of $P$. fluorescens F113

\begin{tabular}{lllll}
\hline Metabolite & Gene involved in biosynthesis & Locus number & Biological Evidence & Reference \\
\hline Pyoverdine & pvdSL; pvdIJKDEONMP; fpvl; pvdA & PSF113_1749-1750; PSF113_1836-1847; & Yes & \\
& & PSF113_1856-1860 & No \\
$\begin{array}{l}\text { Pyridine-2,6-bis-thiocarboxylic } \\
\text { acid (PDTC) }\end{array}$ & pdtCKPELMFGHIJON & PSF113_2605-2618 & Yes \\
2,4 diacetyl-phloroglucinol (DAPG) & phIIEDBCAFGH & PSF113_2457-2464 & Yes \\
Hydrogen cyanide (HCN) & hCnABC & PSF113_2367-2369 & No \\
Putative Lankacidin & IkCABCDEFGJ; pq9FABCDEG & PSF113_3657-3666; PSF113_5383-5388 & No \\
PKS-like metabolite & & PSF113_3045-3053 & No & [83] \\
\hline
\end{tabular}


Streptomyces rochei plasmid pSLA2-L (NC_004808)

\begin{tabular}{|c|c|c|c|c|c|c|c|c|c|c|c|}
\hline$A$ & $B$ & c & $D$ & $E$ & $F$ & $G$ & $H$ & 1 & $J$ & $K \quad L \quad M N$ & 0 \\
\hline p018 & 17 & 16 & 15 & 14 & 13 & 12 & 11 & 10 & 09 & $\begin{array}{llll}08 & 07 & 06 & 05\end{array}$ & 04 \\
\hline
\end{tabular}

Pseudomonas fluorescens F113 (CP003150)

\begin{tabular}{|c|c|c|c|c|c|c|c|c|c|c|c|c|}
\hline & \multicolumn{7}{|c|}{ Ikc } & & & \multicolumn{3}{|c|}{$p q q$} \\
\hline$A$ & $B$ & $c$ & $D$ & $E$ & $H$ & $F$ & $G$ & & & & $B \quad C \quad D$ & $E$ \\
\hline PSF113_3657 & 58 & 59 & 60 & 61 & 62 & 63 & 64 & 65 & 66 & 5383a & $\begin{array}{lll}84 & 85 & 86\end{array}$ & 87 \\
\hline
\end{tabular}

Hahella chejuensis КСTC 2396 (СР000155)

\begin{tabular}{cccccccccc}
\hline$A$ & $B$ & $C$ & $D$ & $E$ & $H$ & $F$ & $G$ \\
$\mathrm{HCH}_{-03491}$ & 90 & 89 & 88 & 87 & 86 & 85 & 84 & 83
\end{tabular}

Figure 6 Comparative genetic analysis of the putative lankacidin biosynthetic cluster. Genes encoding protein involved in biosynthesis of lankacidin are represented as block arrows showing the direction of their transcription. Blue and pink arrows represent protein-coding genes putatively involved in lankacidin biosynthesis and transport, respectively. Green arrows represent protein-coding genes involved in pyrroloquinoline quinone $(P Q Q)$ synthesis. These genes are not present in the genome of Hahella chejuensis KCTC2396.

F113 also carry two prophage elements (P1 and P2). Prophage P1 $(16,984 \mathrm{bp})$ is, like the prophages of other P. fluorescens strains [90], inserted between two highly conserved genes: mutS (PSF113_1167) and $\operatorname{cin} A$ (PSF113_1173). Prophage P1 closely resembles to prophage Pp1 of P. fluorescens SBW25 [18,90] and carries conserved tail synthesis genes of phage CTX but lacks integrase and head morphogenesis genes. Therefore this genomic region probably encodes a bacteriocin belonging to the R-type pyocins. The second prophage of P. fluorescens F113 ( $41,823 \mathrm{bp}$ ) is related to prophage 03 of $P$. fluorescens Pf- 5 [90]. This genomic region contains protein-coding genes involved in tail assembly and head morphogenesis and therefore could correspond to the genome of a bacteriophage.

\section{Conclusions}

Genome analysis of strain F113 has shown that this bacterium belongs to the Pseudomonas fluorescens complex. However, as indicated earlier by Silby et al. [18] and more recently by Loper et al. [20], the taxonomy of $P$. fluorescens requires further study, since significant differences are found in the genomic complement of different strains. Furthermore, the phylogenomic analysis has shown that the $P$. fluorescens group can be subdivided into at least, five subgroups. Indeed, while F113 shared only $35 \%$ of its genome with all the other sequenced strains within the $P$. fluorescens group, this value increases to $76 \%$ when the $\mathrm{F} 113$ genome is compared to the four closest relatives $(P$. brassicacearum Q8r1-96, P. brassicacearum NFM421, P. fluorescens WoodR1 and P. fluorescens Q2-87 genomes). The fact that these strains have common unusual traits such as denitrification, phenotypic variation during rhizosphere colonization $[14,91,92]$ and highly conserved and unique chemotaxis systems, might indicate that these strains belong to the same species. In addition F113 genome contains 344 genes that are not found in Q2-87, Q8r1-96, WoodR1 and NFM421, which encode proteins likely to be involved in the production of an unknown polyketide and in the assembly of a second flagella. These traits could explain in part the excellent rhizocompetence ability of F113 and are currently under study. 


\section{Methods}

\section{Bioinformatic analysis}

Pseudomonas predicted proteomes were downloaded from the PATRIC ftp server [93] (Additional file 1). Whole-genome based phylogenetic trees were built by using a Composition Vector approach [22,94] using the web server CVTree [95] with a peptide window (k value) equal to 6. Trees were generated by Neighbor joining algorithm using as outgroup Escherichia coli K12 when analysing the whole Pseudomonas genus and $P$. aeruginosa PAO1 when analysing P. fluorescens group. Phylogenetic trees were visualized and exported using MEGA software v5 [96].

Orthologous CDSs in the fifty genomes within the $P$. fluorescens group (Additional file 1) were defined after comparing all-against-all using BLASTP and processed by OrthoMCL pipeline using default settings, match percentage cut-off $50 \%$ and an expected value of $1 \mathrm{e}-5$ [25]. Own designed perl scripts and SQL queries were used to filter results. Venn diagram was drawn using R-project language [97] and gplots package [98].

Genome rearrangement between the complete genomes sequences of $P$. fluorescens F113, P. brassicacearum subsp. brassicacearum NFM421 and P. fluorescens Pf0-1 was assessed by using Mauve software with a window of 1000 nucleotides [99].

The ORFs of $P$. aeruginosa PAO1, P. fluorescens Pf-5, $P$. putida KT2440 and P. syringae pv. tomato DC3000 were used as queries in BLASTP searches, expected value lower than $1 \mathrm{e}-5$, to identify homologues of TolC (T1SS), XcpR (T2SS), HrcV (T3SS), VirB4 (T4SS), EstA (T5aSS), TpsB (T5bSS), PlpD (T5dSS) and IglA (T6SS) in all Pseudomonas predicted proteomes available at the time of analysis. The retrieved sequences were verified using the conserved domain database (CDD) [100]. Protein sequences were aligned using MAFFT [101]. Maximum-likelihood (ML) trees with were built with PhyML [102] using the WAG amino acid substitution model of evolution [103] and four categories of substitution rates. Branch supports were evaluated using the approximate likelihood-ratio test (aLRT) [104]. Phylogenetic trees were visualized and exported using the web-based tool Interactive Tree Of Life (iTol) [105].

\section{Metabolic and motility assays}

Denitrification tests were carried out using P. fluorescens F113 and Pf0-1. Inoculi from both strains were obtained from overnight cultures grown in LB medium [106]. Assays were performed in LB medium alone or supplemented either with $20 \mathrm{mM}$ of $\mathrm{KNO}_{3}$ or $10 \mathrm{mM}$ of $\mathrm{NaNO}_{2}$. Argon gas was used to create anaerobic conditions by purging it into the medium. Presence or absence of $\mathrm{NaNO}_{2}$ was checked using NitriVer ${ }^{\circledR} 5$ Nitrite Reagent Powder Pillows (HACH. Düsseldorf, Germany).
Growth on abietic acid (Sigma. Steinhelm, Germany) was tested by colony counts after 20 days cultivation in minimal medium $\left(0.1 \mathrm{~g} / \mathrm{L} \mathrm{NaCl}, 0.1 \mathrm{~g} / \mathrm{L} \mathrm{MgSO}_{4} 7 \mathrm{H}_{2} \mathrm{O}\right.$, $\left.1 \mathrm{~g} / \mathrm{L} \mathrm{K}_{2} \mathrm{HPO}_{4}, 0.5 \mathrm{~g} / \mathrm{L} \mathrm{KH}_{2} \mathrm{PO}_{4}, 1 \mathrm{~g} / \mathrm{L} \mathrm{NH}_{4} \mathrm{SO}_{4}\right)$ supplemented with $1 \mathrm{ml} / \mathrm{L}$ PAS salts $\left(19.5 \mathrm{~g} / \mathrm{L} \mathrm{MgSO}_{4}, 5 \mathrm{~g} / \mathrm{L}\right.$

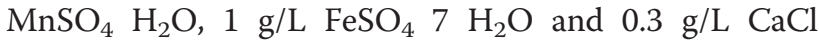
$\mathrm{H}_{2} \mathrm{O}$ ) and with $0.01 \%$ abietic acid. Cells from strains F113 and Pf0-1 were conditioned for 10 days in this medium. Approximately $10^{4}$ cells from these cultures were inoculated in the same medium and incubated 20 days at $28^{\circ} \mathrm{C}$. Dilutions of these cultures were plated on SA medium and colonies were counted.

SA medium plates containing $0.3 \%$ purified agar were used to test swimming abilities. The cells from exponentially growing cultures were inoculated into the plates using a toothpick. Swimming haloes were checked after $18 \mathrm{~h}$ of inoculation. Every assay was performed three times with three replicates each time.

ACC deaminase activity was measured by determining the production of $\alpha$-ketobutyrate from 1-amino-1-cyclopropane carboxylic acid (ACC). The strain was cultured at $30^{\circ} \mathrm{C}$ overnight in $4.75 \mathrm{ml}$ Pseudomonas minimal media broth supplemented with $0.15 \%$ glucose, $1 \%$ sodium citrate and $0.25 \mathrm{ml}$ of $0.5 \mathrm{M}$ ACC. The cells were harvested by centrifugation ( $2 \mathrm{~min}$ at $13,000 \mathrm{rpms}$ ) and resuspended in $0.2 \mathrm{ml} 0.1 \mathrm{M}$ Tris- $\mathrm{HCl}$ (pH 7.5). $10 \mu \mathrm{l}$ of toluene was added to the cell suspension and mixed. $50 \mu \mathrm{L}$ of the toluenised cells were transferred into a clean dry eppendroff tube. $5 \mu \mathrm{L}$ of $0.5 \mathrm{M}$ ACC was added into the tube and incubated for $30 \mathrm{~min}$ at $30^{\circ} \mathrm{C} .500 \mu \mathrm{L}$ of $0.56 \mathrm{M} \mathrm{HCl}$ was added into the tube and vortexed. The cell debris was removed by centrifugation and $500 \mu \mathrm{L}$ of the supernatant was transferred to a clean tube. $400 \mu \mathrm{L}$ of $0.56 \mathrm{M} \mathrm{HCl}$ and $150 \mu \mathrm{L}$ of $2 \% 2-4$ dinitrophenylhydrazine solution were added and the mixture was incubated at $30^{\circ} \mathrm{C}$ for 30 mins. $1 \mathrm{ml}$ of $2 \mathrm{M} \mathrm{NaOH}$ was then added to the samples. The absorbance of each sample was measured at $540 \mathrm{~nm}$. $\alpha$-ketobutyrate concentrations were calculated from a standard curve created using $\alpha$-ketobutyrate standards.

\section{Additional files}

Additional file 1: Characteristics of sequenced genomes from the $P$. fluorescens group (as of 20-11-2012).

Additional file 2: Physical map of the Pseudomonas fluorescens F113 genome. Arrows in the outer circles show CDS (in green), tRNA (in red) and rRNA (in yellow). Gene clusters described in the article are highlighted in the map. Center circle shows $\mathrm{G} / \mathrm{C} \%$ distribution.

Additional file 3: List of F113 CDSs that are not present or are below the threshold to be considered as orthologous in other strains belonging to the $P$. fluorescens Subgroup I. Closest homologues are included in the Table.

Additional file 4: Distribution of denitrification pathway in strains belonging to the $P$. fluorescens group. 


\section{Additional file 5: Distribution of chemotaxis systems in strains belonging to the $P$. fluorescens group.}

Additional file 6: Repertoire of T2SSs, T3SSs and T6SSs in the Pseudomonas genus.

Additional file 7: Phylogenetic distribution of T2SSs within Pseudomonas species. A distance tree (Maximum-Likelihood) was calculated from 200 XcpR-like proteins of Pseudomonas spp. T2SSs of Pseudomonas spp. can be divided in two distinct phylogenetic clusters: X $\mathrm{cp}$ and $\mathrm{Hxc}$ highlighted in red and blue, respectively. The XcpR-like proteins related to the $\mathrm{Hpl}$ cluster are used as out group. Genes of $P$. fluorescens F113 encoding potential T2SSs are represented as block arrows showing the direction of their transcription. Numbers represented the PSF113 locus IDs. Black arrows represented genes encoding the T2S machinery, whereas grey arrows represented gene encoding protein with unknown function. White arrows represented genes encoding putative T2SS-substrates.

\section{Additional file 8: Phylogenetic distribution of T3SSs within}

Pseudomonas species. A distance tree (Maximum-Likelihood) was calculated from $146 \mathrm{HrCV}$-like proteins of Pseudomonas spp. Green, orange, and blue labels indicate HrCV-like proteins related to Hrp1, SPI-1, Rhizobiales, and Ysc systems, respectively. Genes of P. fluorescens F113 encoding T3SSs are represented as block arrows showing the direction of their transcription. Numbers represented the PSF113 locus IDs. Black arrows represented genes encoding the T3S machinery, whereas grey arrows represented gene encoding protein with unknown function. White arrows represented genes encoding putative T3SS-substrates and chaperones.

Additional file 9: GC content analysis of the SPI-1 clusters encoded in different strains belonging to the Pseudomonas genus. Asterisks indicate that the SPI-1 cluster is located on two different scaffolds.

\section{Additional file 10: Phylogenetic distribution of T6SSs within}

Pseudomonas species. A distance tree (Maximum-Likelihood) was calculated from $345 \mathrm{Ig} / \mathrm{A}$ proteins of Pseudomonas spp. T6SSs of Pseudomonas spp. can be divided into five mains clusters (1, 2, 3, 4A and $4 \mathrm{~B})$ highlighted in red, yellow, green, blue and purple, respectively. Genes of $P$. fluorescens F113 encoding T6SSs are represented as block arrows showing the direction of their transcription. Numbers represented the PSF113 locus IDs. Black arrows represented genes encoding the T6S machinery, whereas grey arrows represented gene encoding protein with unknown function.

\section{Competing interests}

The authors declare that they have no competing interests.

\section{Authors' contributions}

MR-N and MB performed the, phylogenomic analysis and bioinformatic analysis and participated in drafting the Ms. JM and JAM contributed to the bioinformatic analysis. KG carried out studies on the expression of ACC deaminase. FM-G, EB, AN and MR-N analyzed motility genes and performed motility experiments. CM and MR-N analyzed the denitrification and chemotaxis genes and performed experiments on these two traits. MS-C analyzed genes implicated in virulence and performed growth experiments on abietic acid and on interaction with invertebrates. JM, DD, FOG, MM and RR were involved in the conception of the study, participated in its design and coordination, supervised work and wrote the Ms. All authors read and approved the final manuscript.

\section{Acknowledgements}

Research at UAM was funded by grants MICROAMBIENTE-CM (to R.R.), BIO2009-08254 (to M.M.), and Marie Curie MIGENOF113 (to M.S.-C. and R.R.). This research was supported in parts by grants awarded to FOG by the Science Foundation of Ireland (07IN.1/B948, 08/RFP/GEN1295, 08/RFP/ GEN1319, SFI09/RFP/BMT2350); the Department of Agriculture, Fisheries and Food (RSF grants 06-321 and 06-377; FIRM grants 06RDC459 06RDC506 and 08RDC629); the European Commission (MTKD-CT-2006-042062, Marie Curie TOK:TRAMWAYS, EU256596, MicroB3-287589-OCEAN2012, MACUMBA-CP-TP 311975; PharmaSea-CP-TP 312184); IRCSET (05/EDIV/FP107/INTERPAM, EMBARK), the Marine Institute Beaufort award (C\&CRA 2007/082), the Environmental Protection Agency (EPA 2006-PhD-S-21, EPA 2008-PhD-S-2) and the HRB (RP/2006/271, RP/2007/290, HRA/2009/146). The Lab of KG \&
DD was in part funded by an SFI Tida award and the Department of Education TSR III Agribiotics project.

The authors would like to acknowledge the Centro de Computación Científica at Universidad Autónoma de Madrid and the Boole Centre for Research in Informatics at University College Cork for providing access to computational facilities.

\section{Author details}

'Departamento de Biología, Facultad de Ciencias, Universidad Autónoma de Madrid, c/Darwin, 2, Madrid 28049, Spain. 'BIOMERIT Research Centre, Microbiology Department, University College Cork, Cork, Ireland. ${ }^{3}$ Microbiology Department, Food Science Building, University College Cork, Cork, Ireland. "Institute of Technology, Carlow, Ireland.

Received: 17 July 2012 Accepted: 23 January 2013 Published: 25 January 2013

\section{References}

1. Shanahan P, O'Sullivan DJ, Simpson P, Glennon JD, O'Gara F: Isolation of 2,4-diacetylphloroglucinol from a fluorescent pseudomonad and investigation of physiological parameters influencing its production. Appl Environ Microbiol 1992, 58(1):353-358.

2. Cronin D, Moenne-Loccoz T, Fenton A, Dunne C, Dowling DN, O'gara F: Ecological interaction of a biocontrol Pseudomonas fluorescens strain producing 2,4-diacetylphloroglucinol with the soft rot potato pathogen Erwinia carotovora subsp. atroseptica. FEMS Microbiol Ecol 1997, 23(2):95-106.

3. Barahona E, Navazo A, Martinez-Granero F, Zea-Bonilla T, Perez-Jimenez RM, Martin M, Rivilla R: Pseudomonas fluorescens F113 mutant with enhanced competitive colonization ability and improved biocontrol activity against fungal root pathogens. Appl Environ Microbiol 2011, 77(15):5412-5419.

4. Fenton AM, Stephens PM, Crowley J, O'Callaghan M, O'Gara F: Exploitation of gene(s) involved in 2,4-diacetylphloroglucinol biosynthesis to confer a new biocontrol capability to a Pseudomonas strain. Appl Environ Microbiol 1992, 58(12):3873-3878.

5. Cronin D, Moenne-Loccoz Y, Fenton A, Dunne C, Dowling DN, O'Gara F: Role of 2,4-Diacetylphloroglucinol in the Interactions of the Biocontrol Pseudomonad Strain F113 with the Potato Cyst Nematode Globodera rostochiensis. Appl Environ Microbiol 1997, 63(4):1357-1361.

6. Abbas A, Morrissey JP, Marquez PC, Sheehan MM, Delany IR, O'Gara F: Characterization of interactions between the transcriptional repressor $\mathrm{PhlF}$ and its binding site at the phIA promoter in Pseudomonas fluorescens F113. J Bacteriol 2002, 184(11):3008-3016.

7. Frapolli M, Pothier JF, Defago G, Moenne-Loccoz Y: Evolutionary history of synthesis pathway genes for phloroglucinol and cyanide antimicrobials in plant-associated fluorescent pseudomonads. Mol Phylogenet Evol 2012, 63(3):877-890.

8. Moynihan JA, Morrissey JP, Coppoolse ER, Stiekema WJ, O'Gara F, Boyd EF: Evolutionary history of the phl gene cluster in the plant-associated bacterium Pseudomonas fluorescens. Appl Environ Microbiol 2009, 75(7):2122-2131.

9. De La Fuente L, Landa BB, Weller DM: Host crop affects rhizosphere colonization and competitiveness of 2,4-Diacetylphloroglucinolproducing Pseudomonas fluorescens. Phytopathology 2006, 96(7):751-762.

10. Villacieros M, Power B, Sánchez-Contreras M, Lloret J, Oruezabal Rl, Martín M, Fernández-Piñas F, Bonilla I, Whelan C, Dowling DN, et al: Colonization behaviour of Pseudomonas fluorescens and Sinorhizobium meliloti in the alfalfa (Medicago sativa) rhizosphere. Plant Soil 2003, 251(1):47-54.

11. De Carcer DA, Martin M, Mackova M, Macek T, Karlson U, Rivilla R: The introduction of genetically modified microorganisms designed for rhizoremediation induces changes on native bacteria in the rhizosphere but not in the surrounding soil. ISME J 2007, 1(3):215-223.

12. Rein A, Fernqvist MM, Mayer $P$, Trapp S, Bittens M, Karlson UG: Degradation of PCB congeners by bacterial strains. Appl Microbiol Biotechnol 2007, 77(2):469-481.

13. Barahona E, Navazo A, Yousef-Coronado F, Aguirre De Carcer D, MartinezGranero F, Espinosa-Urgel M, Martin M, Rivilla R: Efficient rhizosphere colonization by Pseudomonas fluorescens F113 mutants unable to form biofilms on abiotic surfaces. Environ Microbio/ 2010, 12(12):3185-3195.

14. Martínez-Granero F, Rivilla R, Martin M: Rhizosphere selection of highly motile phenotypic variants of Pseudomonas fluorescens with enhanced competitive colonization ability. Appl Environ Microbiol 2006, 72(5):3429-3434. 
15. Villacieros M, Whelan C, Mackova M, Molgaard J, Sánchez-Contreras M, Lloret J, De Carcer DA, Oruezabal RI, Bolaños L, Macek T, et al: Polychlorinated biphenyl rhizoremediation by Pseudomonas fluorescens F113 derivatives, using a Sinorhizobium meliloti nod system to drive bph gene expression. Appl Environ Microbiol 2005, 71(5):2687-2694.

16. Mulet M, Lalucat J, Garcia-Valdes E: DNA sequence-based analysis of the Pseudomonas species. Environ Microbiol 2010, 12(6):1513-1530.

17. Ramette A, Frapolli M, Fischer-Le Saux M, Gruffaz C, Meyer JM, Defago G, Sutra L, Moenne-Loccoz Y: Pseudomonas protegens sp. nov., widespread plant-protecting bacteria producing the biocontrol compounds 2,4-diacetylphloroglucinol and pyoluteorin. Syst Appl Microbiol 2011, 34(3):180-188.

18. Silby M, Cerdeno-Tarraga A, Vernikos G, Giddens S, Jackson R, Preston G, Zhang X-X, Moon C, Gehrig S, Godfrey S, et al: Genomic and genetic analyses of diversity and plant interactions of Pseudomonas fluorescens. Genome Biol 2009, 10(5):R51.

19. Goris J, Konstantinidis KT, Klappenbach JA, Coenye T, Vandamme P, Tiedje JM: DNA-DNA hybridization values and their relationship to wholegenome sequence similarities. Int J Syst Evol Microbiol 2007, 57(Pt 1):81-91.

20. Loper JE, Hassan KA, Mavrodi DV, Davis EW 2nd, Lim CK, Shaffer BT, Elbourne LD, Stockwell VO, Hartney SL, Breakwell K, et al: Comparative genomics of plant-associated Pseudomonas spp.: insights into diversity and inheritance of traits involved in multitrophic interactions. PLOS Genet 2012, 8(7):e1002784

21. Redondo-Nieto M, Barret M, Morrisey JP, Germaine K, Martinez-Granero F, Barahona E, Navazo A, Sanchez-Contreras M, Moynihan JA, Giddens SR, et al: Genome sequence of the biocontrol strain Pseudomonas fluorescens F113. J Bacteriol 2012, 194(5):1273-1274

22. Qi J, Wang B, Hao BI: Whole proteome prokaryote phylogeny without sequence alignment: a K-string composition approach. J Mol Evol 2004, 58(1):1-11.

23. Kämpfer $P$, Glaeser SP: Prokaryotic taxonomy in the sequencing era - the polyphasic approach revisited. Environ Microbiol 2012, 14(2):291-317.

24. Ortet $P$, Barakat M, Lalaouna D, Fochesato S, Barbe V, Vacherie B, Santaella C, Heulin T, Achouak W: Complete genome sequence of a beneficial plant root-associated bacterium. Pseudomonas brassicacearum. J Bacteriol 2011, 193(12):3146

25. Li L, Stoeckert CJ Jr, Roos DS: OrthoMCL: identification of ortholog groups for eukaryotic genomes. Genome Res 2003, 13(9):2178-2189.

26. Ghiglione JF, Gourbiere F, Potier P, Philippot L, Lensi R: Role of respiratory nitrate reductase in ability of Pseudomonas fluorescens YT101 to colonize the rhizosphere of maize. Appl Environ Microbiol 2000, 66(9):4012-4016.

27. Rediers H, Vanderleyden J, De Mot R: Nitrate respiration in Pseudomonas stutzeri A15 and its involvement in rice and wheat root colonization. Microbiol Res 2009, 164(4):461-468.

28. Pothier JF, Prigent-Combaret C, Haurat J, Moenne-Loccoz Y, Wisniewski-Dye F: Duplication of plasmid-borne nitrite reductase gene nirK in the wheatassociated plant growth-promoting rhizobacterium Azospirillum brasilense Sp245. Mol Plant Microbe Interact 2008, 21(6):831-842.

29. Ghiglione JF, Richaume A, Philippot L, Lensi R: Relative involvement of nitrate and nitrite reduction in the competitiveness of Pseudomonas fluorescens in the rhizosphere of maize under non-limiting nitrate conditions. FEMS Microbiol Ecol 2002, 39(2):121-127.

30. Philippot L, Clays-Josserand A, Lensi R: Use of tn 5 mutants to assess the role of the dissimilatory nitrite reductase in the competitive abilities of two pseudomonas strains in soil. Appl Environ Microbiol 1995, 61(4):1426-1430.

31. Ghirardi S, Dessaint F, Mazurier S, Corberand T, Raaijmakers JM, Meyer JM, Dessaux Y, Lemanceau P: Identification of traits shared by rhizospherecompetent strains of fluorescent Pseudomonads. Microb Ecol 2012, 64(3):725-737.

32. Jones CM, Welsh A, Throback IN, Dorsch P, Bakken LR, Hallin S: Phenotypic and genotypic heterogeneity among closely related soil-borne $\mathrm{N}_{2}$ - and $\mathrm{N}_{2} \mathrm{O}$-producing Bacillus isolates harboring the nosZ gene. FEMS Microbiol Ecol 2011, 76(3):541-552.

33. Witzig R, Aly HA, Strompl C, Wray V, Junca H, Pieper DH: Molecular detection and diversity of novel diterpenoid dioxygenase DitA1 genes from proteobacterial strains and soil samples. Environ Microbiol 2007, 9(5):1202-1218.

34. Martin VJ, Mohn WW: Genetic investigation of the catabolic pathway for degradation of abietane diterpenoids by Pseudomonas abietaniphila BKME-9. J Bacteriol 2000, 182(13):3784-3793.
35. Morgan CA, Wyndham RC: Characterization of $t d t$ genes for the degradation of tricyclic diterpenes by Pseudomonas diterpeniphila A19-6a. Can J Microbiol 2002, 48(1):49-59.

36. Mathee K, Narasimhan G, Valdes C, Qiu X, Matewish JM, Koehrsen M, Rokas A Yandava CN, Engels R, Zeng E, et al: Dynamics of Pseudomonas aeruginosa genome evolution. Proc Natl Acad Sci USA 2008, 105(8):3100-3105.

37. Miller SH, Browne P, Prigent-Combaret C, Combes-Meynet E, Morrissey JP, O'Gara F: Biochemical and genomic comparison of inorganic phosphate solubilization in Pseudomonas species. Environ Microbiol Reports 2010, 2(3):403-411.

38. Rice O, Miller SH, Morrissey JP, O'Gara F: Exploitation of glucose catabolic gene fusions to investigate in situ expression during Pseudomonas-plant interactions. Biol Fertil Soils 2012, 48(2):235-238.

39. Monds RD, Newell PD, Schwartzman JA, OToole GA: Conservation of the Pho regulon in Pseudomonas fluorescens Pf0-1. Appl Environ Microbiol 2006, 72(3):1910-1924.

40. Lim BL, Yeung P, Cheng C, Hill JE: Distribution and diversity of phytatemineralizing bacteria. ISME J 2007, 1(4):321-330.

41. Blaha D, Prigent-Combaret C, Mirza MS, Moenne-Loccoz Y: Phylogeny of the 1-aminocyclopropane-1-carboxylic acid deaminase-encoding gene acdS in phytobeneficial and pathogenic Proteobacteria and relation with strain biogeography. FEMS Microbiol Ecol 2006, 56(3):455-470.

42. Glick BR, Todorovic B, Czarny J, Cheng ZY, Duan J, McConkey B: Promotion of plant growth by bacterial ACC deaminase. Crit Rev Plant Sci 2007, 26(5-6):227-242.

43. Holguin G, Glick BR: Expression of the ACC deaminase gene from Enterobacter cloacae UW4 in Azospirillum brasilense. Microb Ecol 2001, 41(3):281-288

44. Capdevila S, Martínez-Granero FM, Sánchez-Contreras M, Rivilla R, Martín M: Analysis of Pseudomonas fluorescens F113 genes implicated in flagellar filament synthesis and their role in competitive root colonization. Microbiology 2004, 150:3889-3897.

45. Redondo-Nieto M, Lloret J, Larenas J, Barahona E, Navazo A, MartinezGranero F, Capdevila S, Rivilla R, Martin M: Transcriptional organization of the region encoding the synthesis of the flagellar filament in Pseudomonas fluorescens. J Bacteriol 2008, 190(11):4106-4109.

46. Martinez-Granero F, Navazo A, Barahona E, Redondo-Nieto M, Rivilla R, Martin M: The Gac-Rsm and SadB signal transduction pathways converge on AlgU to downregulate motility in Pseudomonas fluorescens. PLoS One 2012, 7(2):e31765.

47. Poggio S, Abreu-Goodger C, Fabela S, Osorio A, Dreyfus G, Vinuesa P, Camarena L: A complete set of flagellar genes acquired by horizontal transfer coexists with the endogenous flagellar system in Rhodobacter sphaeroides. J Bacteriol 2007, 189(8):3208-3216.

48. Kim J, Kang Y, Choi O, Jeong Y, Jeong JE, Lim JY, Kim M, Moon JS, Suga H, Hwang I: Regulation of polar flagellum genes is mediated by quorum sensing and FlhDC in Burkholderia glumae. Mol Microbio/ 2007, 64(1):165-179.

49. Navazo A, Barahona E, Redondo-Nieto M, Martinez-Granero F, Rivilla R, Martin M: Three independent signalling pathways repress motility in Pseudomonas fluorescens F113. Microb Biotechnol 2009, 2(4):489-498.

50. Hickman JW, Tifrea DF, Harwood CS: A chemosensory system that regulates biofilm formation through modulation of cyclic diguanylate levels. Proc Natl Acad Sci USA 2005, 102(40):14422-14427.

51. Malone JG, Williams R, Christen M, Jenal U, Spiers AJ, Rainey PB: The structure-function relationship of WspR, a Pseudomonas fluorescens response regulator with a GGDEF output domain. Microbiology 2007 153(4):980-994.

52. Whitchurch CB, Leech AJ, Young MD, Kennedy D, Sargent JL, Bertrand J J, Semmler ABT, Mellick AS, Martin PR, Alm RA, et al: Characterization of a complex chemosensory signal transduction system which controls twitching motility in Pseudomonas aeruginosa. Mol Microbiol 2004, 52(3):873-893.

53. De Weert $\mathrm{S}$, Vermeiren $H$, Mulders IHM, Kuiper I, Hendrickx N, Bloemberg GV, Vanderleyden J, De Mot R, Lugtenberg BJJ: Flagella-driven chemotaxis towards exudate components is an important trait for tomato root colonization by Pseudomonas fluorescens. Mol Plant Microbe Interact 2002, 15(11):1173-1180.

54. Sánchez-Contreras M, Martín M, Villacieros M, O’Gara F, Bonilla I, Rivilla R: Phenotypic selection and phase variation occur during alfalfa root colonization by Pseudomonas fluorescens F113. J Bacteriol 2002, 184(6):1587-1596. 
55. Bleves S, Viarre V, Salacha R, Michel GP, Filloux A, Voulhoux R: Protein secretion systems in Pseudomonas aeruginosa: A wealth of pathogenic weapons. Int J Med Microbiol 2010, 300(8):534-543.

56. Filloux A: The underlying mechanisms of type II protein secretion. Bba-Mol Cell Res 2004, 1694(1-3):163-179.

57. Ball G, Durand E, Lazdunski A, Filloux A: A novel type II secretion system in Pseudomonas aeruginosa. Mol Microbiol 2002, 43(2):475-485.

58. Zhang XX, Scott K, Meffin R, Rainey PB: Genetic characterization of psp encoding the DING protein in Pseudomonas fluorescens SBW25. BMC Microbiol 2007, 7:114.

59. Zaborina O, Holbrook C, Chen Y, Long J, Zaborin A, Morozova I, Fernandez $\mathrm{H}$, Wang Y, Turner JR, Alverdy JC: Structure-function aspects of PstS in multi-drug-resistant Pseudomonas aeruginosa. PLoS Pathog 2008, 4(2):e43.

60. Roy PH, Tetu SG, Larouche A, Elbourne L, Tremblay S, Ren Q, Dodson R, Harkins D, Shay R, Watkins K, et al: Complete genome sequence of the multiresistant taxonomic outlier Pseudomonas aeruginosa PA7. PLOS One 2010, 5(1):e8842.

61. Cornelis GR: The type III secretion injectisome, a complex nanomachine for intracellular 'toxin' delivery. Biol Chem 2010, 391(7):745-751.

62. Pallen MJ, Beatson SA, Bailey CM: Bioinformatics, genomics and evolution of non-flagellar type-III secretion systems: a Darwinian perspective. FEMS Microbiol Rev 2005, 29(2):201-229.

63. Troisfontaines P, Cornelis GR: Type III secretion: more systems than you think. Physiology (Bethesda) 2005, 20:326-339.

64. Mavrodi DV, Joe A, Mavrodi OV, Hassan KA, Weller DM, Paulsen IT, Loper JE, Alfano JR, Thomashow LS: Structural and functional analysis of the type III secretion system from Pseudomonas fluorescens Q8r1-96. J Bacteriol 2011, 193(1):177-189.

65. Rong X, Gurel F, Meulia T, McSpadden Gardener BB: Draft genome sequences of the Pseudomonas fluorescens biocontrol strains Wayne1R and Wood1R. J Bacteriol 2012, 194(3):724-725.

66. Shin SC, Kim SJ, Hong SG, Ahn do H, Lee YM, Lee H, Lee J, Park H: Genome sequence of Pseudomonas sp. strain PAMC 25886, isolated from alpine glacial cryoconite. J Bacteriol 2012, 194(7):1844.

67. Alvarez C, Kukutla P, Jiang J, Yu W, Xu J: Draft genome sequence of Pseudomonas sp. strain Ag1, isolated from the midgut of the malaria mosquito Anopheles gambiae. J Bacterio/ 2012, 194(19):5449.

68. Tribelli PM, Raiger lustman LJ, Catone MV, Di Martino C, Revale S, Mendez BS, Lopez NI: Genome sequence of the polyhydroxybutyrate producer Pseudomonas extremaustralis, a highly stress-resistant Antarctic bacterium. J Bacteriol 2012, 194(9):2381-2382.

69. Kimbrel JA, Givan SA, Halgren AB, Creason AL, Mills DI, Banowetz GM, Armstrong DJ, Chang JH: An improved, high-quality draft genome sequence of the Germination-Arrest Factor-producing Pseudomonas fluorescens WH6. BMC Genomics 2010, 11:522.

70. Mathimaran N, Srivastava R, Wiemken A, Sharma AK, Boller T: Genome sequences of two plant growth-promoting fluorescent pseudomonas strains, R62 and R81. J Bacteriol 2012, 194(12):3272-3273.

71. Patel HK, Da Silva DP, Devescovi G, Maraite H, Paszkiewicz K, Studholme DJ, Venturi V: Draft genome sequence of Pseudomonas fuscovaginae, a broad-host-range pathogen of plants. J Bacterio/ 2012, 194(10):2765-2766.

72. Aschtgen MS, Bernard CS, De Bentzmann S, Lloubes R, Cascales E: SciN is an outer membrane lipoprotein required for type $\mathrm{VI}$ secretion in enteroaggregative Escherichia coli. J Bacteriol 2008, 190(22):7523-7531.

73. Boyer F, Fichant G, Berthod J, Vandenbrouck Y, Attree I: Dissecting the bacterial type VI secretion system by a genome wide in silico analysis: what can be learned from available microbial genomic resources? BMC Genomics 2009, 10:104.

74. Barret M, Egan F, Fargier E, Morrissey JP, O'Gara F: Genomic analysis of the type VI secretion systems in Pseudomonas spp.: novel clusters and putative effectors uncovered. Microbiology 2011, 157(Pt 6):1726-1739.

75. Hood RD, Singh P, Hsu F, Guvener T, Carl MA, Trinidad RR, Silverman JM, Ohlson BB, Hicks KG, Plemel RL, et al: A type VI secretion system of Pseudomonas aeruginosa targets a toxin to bacteria. Cell Host Microbe 2010, 7(1):25-37.

76. Russell AB, Hood RD, Bui NK, LeRoux M, Vollmer W, Mougous JD: Type VI secretion delivers bacteriolytic effectors to target cells. Nature 2011, 475(7356):343-347.

77. Russell AB, Singh P, Brittnacher M, Bui NK, Hood RD, Carl MA, Agnello DM, Schwarz S, Goodlett DR, Vollmer W, et al: A widespread bacterial type VI secretion effector superfamily identified using a heuristic approach. Cell Host Microbe 2012, 11(5):538-549.
78. Lesic B, Starkey M, He J, Hazan R, Rahme LG: Quorum sensing differentially regulates Pseudomonas aeruginosa type VI secretion locus I and homologous loci II and III, which are required for pathogenesis. Microbiology 2009, 155(Pt 9):2845-2855.

79. Sana TG, Hachani A, Bucior I, Soscia C, Garvis S, Termine E, Engel J, Filloux A, Bleves $S$ : The second type six secretion system of Pseudomonas aeruginosa strain PAO1 is regulated by quorum sensing and fur, and modulates internalization in epithelial cells. J Biol Chem 2012, 287(32):27095-27105.

80. Hachani A, Lossi NS, Hamilton A, Jones C, Bleves S, Albesa-Jove D, Filloux A: Type VI secretion system in Pseudomonas aeruginosa: secretion and multimerization of VgrG proteins. J Biol Chem 2011, 286(14):12317-12327.

81. Andersson PF, Levenfors J, Broberg A: Metabolites from Pseudomonas brassicacearum with activity against the pink snow mould causing pathogen Microdochium nivale. Biocontrol 2012, 57(3):463-469.

82. Lewis TA, Leach L, Morales S, Austin PR, Hartwell HJ, Kaplan B, Forker C, Meyer JM: Physiological and molecular genetic evaluation of the dechlorination agent, pyridine-2,6-bis(monothiocarboxylic acid) (PDTC) as a secondary siderophore of Pseudomonas. Environ Microbiol 2004, 6(2):159-169.

83. Aarons S, Abbas A, Adams C, Fenton A, O'Gara F: A regulatory RNA (PrrB RNA) modulates expression of secondary metabolite genes in Pseudomonas fluorescens F113. J Bacterio/ 2000, 182(14):3913-3919.

84. Suwa M, Sugino H, Sasaoka A, Mori E, Fujii S, Shinkawa H, Nimi O, Kinashi H: Identification of two polyketide synthase gene clusters on the linear plasmid pSLA2-L in Streptomyces rochei. Gene 2000, 246(1-2):123-131.

85. Arakawa K, Sugino F, Kodama K, Ishii T, Kinashi H: Cyclization mechanism for the synthesis of macrocyclic antibiotic lankacidin in Streptomyces rochei. Chem Biol 2005, 12(2):249-256

86. Tatsuno S, Arakawa K, Kinashi H: Extensive mutational analysis of modulariterative mixed polyketide biosynthesis of lankacidin in Streptomyces rochei. Biosci Biotechnol Biochem 2009, 73(12):2712-2719.

87. Olcott MH, Henkels MD, Rosen KL, Walker FL, Sneh B, Loper JE, Taylor BJ: Lethality and developmental delay in Drosophila melanogaster larvae after ingestion of selected Pseudomonas fluorescens strains. PLoS One 2010, 5(9):e12504

88. Tennant SM, Skinner NA, Joe A, Robins-Browne RM: Homologues of insecticidal toxin complex genes in Yersinia enterocolitica biotype $1 \mathrm{~A}$ and their contribution to virulence. Infect Immun 2005, 73(10):6860-6867.

89. Juhas M, Crook DW, Dimopoulou ID, Lunter G, Harding RM, Ferguson DJ, Hood DW: Novel type IV secretion system involved in propagation of genomic islands. J Bacteriol 2007, 189(3):761-771.

90. Mavrodi DV, Loper JE, Paulsen IT, Thomashow LS: Mobile genetic elements in the genome of the beneficial rhizobacterium Pseudomonas fluorescens Pf-5. BMC Microbiol 2009, 9:8.

91. Achouak W, Conrod S, Cohen V, Heulin T: Phenotypic variation of Pseudomonas brassicacearum as a plant root-colonization strategy. $\mathrm{Mol}$ Plant Microbe Interact 2004, 17(8):872-879.

92. Mavrodi OV, Mavrodi DV, Weller DM, Thomashow LS: Role of ptsP, orfT, and sss recombinase in root colonization by Pseudomonas fluorescens Q8r1-96. Appl Environ Microbio/ 2006, 72(11):7111-7122.

93. Gillespie JJ, Wattam AR, Cammer SA, Gabbard JL, Shukla MP, Dalay O, Driscoll T, Hix D, Mane SP, Mao C, et al: PATRIC: the comprehensive bacterial bioinformatics resource with a focus on human pathogenic species. Infect Immun 2011, 79(11):4286-4298.

94. Li Q, Xu Z, Hao B: Composition vector approach to whole-genome-based prokaryotic phylogeny: success and foundations. J Biotechnol 2010, 149(3):115-119.

95. CVTree. Composition Vector Tree. http://tlife.fudan.edu.cn/cvtree/.

96. Tamura K, Peterson D, Peterson N, Stecher G, Nei M, Kumar S: MEGA5: Molecular evolutionary genetics analysis using maximum likelihood, evolutionary distance, and maximum parsimony methods. Mol Biol Evol 2011, 28(10):2731-2739.

97. R-Project. http://www.r-project.org/.

98. gplots: Various R programming tools for plotting data. http://cran.r-project. org/web/packages/gplots/index.html.

99. Darling AE, Mau B, Perna NT: progressiveMauve: multiple genome alignment with gene gain, loss and rearrangement. PLOS One 2010, 5(6):e11147.

100. Marchler-Bauer A, Lu S, Anderson JB, Chitsaz F, Derbyshire MK, DeWeeseScott C, Fong JH, Geer LY, Geer RC, Gonzales NR, et al: CDD: a Conserved 
Domain Database for the functional annotation of proteins. Nucleic Acids Res 2011, 39(Database issue):D225-229.

101. Katoh K, Toh H: Recent developments in the MAFFT multiple sequence alignment program. Brief Bioinform 2008, 9(4):286-298,

102. Guindon S, Gascuel O: A simple, fast, and accurate algorithm to estimate large phylogenies by maximum likelihood. Syst Biol 2003, 52(5):696-704.

103. Whelan S, Goldman N: A general empirical model of protein evolution derived from multiple protein families using a maximum-likelihood approach. Mol Biol Evol 2001, 18(5):691-699.

104. Anisimova M, Gascuel O: Approximate likelihood-ratio test for branches: A fast, accurate, and powerful alternative. Syst Biol 2006, 55(4):539-552.

105. Letunic I, Bork P: Interactive Tree Of Life v2: online annotation and display of phylogenetic trees made easy. Nucleic Acids Res 2011 39(Web Server issue):W475-W478.

106. Bertani G: Studies on lysogenesis. 1. The mode of phage liberation by lysogenic Escherichia coli. J Bacteriol 1951, 62(3):293-300.

doi:10.1186/1471-2164-14-54

Cite this article as: Redondo-Nieto et al:: Genome sequence reveals that Pseudomonas fluorescens $\mathrm{F} 113$ possesses a large and diverse array of systems for rhizosphere function and host interaction. BMC Genomic 2013 14:54

\section{Submit your next manuscript to BioMed Central and take full advantage of:}

- Convenient online submission

- Thorough peer review

- No space constraints or color figure charges

- Immediate publication on acceptance

- Inclusion in PubMed, CAS, Scopus and Google Scholar

- Research which is freely available for redistribution 